\section{SOI: $1.1 /$ TAS DOI: $10.15863 / \mathrm{TAS}$ International Scientific Journal Theoretical \& Applied Science}

p-ISSN: 2308-4944 (print) e-ISSN: 2409-0085 (online)

Year: $2018 \quad$ Issue: $01 \quad$ Volume: 57

Published: $30.01 .2018 \quad$ http://T-Science.org
Khabibullo Khakimovich Khusanov senior teacher of the chair of

"Theory and practice of building democratic society in Uzbekistan" of Andizhan State University, Republic of Uzbekistan

\title{
SECTION 13.History.
}

\section{THE DEATH OF ARAL SEA AND ITS ECOLOGICAL CONSEQUENCES}

Abstract: In this article has been analyzed the death and tragedy of Aral Sea and its negative consequences as well as its influences to environment by the historical literatures and archive materials. The information showed that the amount of water is decreasing rapidly year by year. As a result, in recent 20-25 years as the result of intensive development of irrigated farming, industry and everyday services the inflow of river water into the Aral Sea sharply decreased.

Key words: Aral Sea, ecology, ecological policy, salty diseases, global issues.

Language: English

Citation: Khusanov KK (2018) THE DEATH OF ARAL SEA AND ITS ECOLOGICAL CONSEQUENCES. ISJ Theoretical \& Applied Science, 01 (57): 250-252.

Soi: http://s-o-i.org/1.1/TAS-01-57-40 Doi: crossef https://dx.doi.org/10.15863/TAS.2018.01.57.40

\section{Introduction.}

At present time, there are a lot of catastrophic problems and ecological troubles in the world. Everyone knows that one of the worst global issues is the tragedy of Aral Sea. The Aral Sea, on the border between Uzbekistan and Kazakhstan yet it has been disappearing for many times. Since the 1920s, Soviet agricultural planners have used up the Aral Sea, diverting its waters to irrigate cotton. The two rivers feeding the Aral were drawn off to irrigate millions of hectares of cotton. The irrigation canal, the world's longest, stretches over 1,300 kilometers, paralleling the boundaries of Afghanistan and Iran. The cotton production plan worked, and by 1937, the former Soviet Union became a new exporter of cotton [4]. The success of the cotton program, however, was to spell the end for the Aral Sea.

For a long time ecological impact on the sea and surrounding area was largely hidden from public view. Since the 1960s, however the Aral has lost about 40 percent of its surface area, or almost 20,000 square kilometers of what are now largely dry, saltencrusted wastelands. The once-thriving fishing industry that depended on the water is all but gone. Another apparent consequence is a host of human illnesses. A high rate of throat cancer is attributed to dust from the drying sea. In the northwest part of the republic of Uzbekistan, the infant-mortality rate is the highest in the Soviet Union.

The amount of water is decreasing year by year. In recent 20-25 years as the result of intensive development of irrigated farming, industry and everyday services the inflow of river water into the Aral Sea sharply decreased. Water level reduced by 14 metres, and salinity increased 3 times. The sea was divided into two reservoirs - the big and small one - and lost its fishing and transportation value. The former bottom of the sea (about 30 thousands sq $\mathrm{km})$ requires urgent measures on soil stabilizations, otherwise it becomes the object of intensive wind erosion and salt spreading. That is why the people nearby living of Aral Sea they are suffering from incurable illnesses. For instance, different kind of cancer diseases [8].

The Aral Sea is also one of the largest internal water non-dischargeable reservoirs in the world which was formed as the result of inflow of two large rivers of Central Asia-Amudarya and Syrdarya. In former times not less than 50-55 billion cubic metres of fresh water ran into it, that is why salt content of water was only 9-10 gm per litre [5]. As the result, it was rich in fish including fresh-water fish. Being located between two Central Asian deserts - the Karakum and the Kizilkum - it played the role of stabilizer preventing the formation of new deserts. In addition, it played definite role in land reclamation being a natural reservoir for salt transported by river and collector-drainage effluent from all irrigated land.

Such ecological problems as a disastrous situation in the Aral Sea and adjacent regions; high anthropogenic load on environment in Tashkent region and the Fergana valley; shortage of potable water; degeneration of pastures; salinization and 
erosion of irrigated land; soil contamination with pesticides; etc. are the problems to be eliminated urgently[7].

Going to the detail this tragedy was began in 1960. The main reasons of decreasing Aral Sea are works of irrigation and land reclamation in virgin lands and found a lot of cotton state farms. In 19601990 water sources were used in the cotton fields. Therefore, cotton-growing in this period was developed. Development of cotton growing depended on increasing irrigation. That's why lots of irrigation structures were constructed in the Republic. "In 1951-1955 irrigation structures were constructed on the basins of the Syrdarya, Kashkadarya, Zarafshan rivers, in the territory of Central Ferghana, on the banks of Surkhandarya and Amudarya. $183 \mathrm{~km}$ long Eski Angar canal was constructed which pours water from the Zarafshan river into the Kashkadarya river." And the construction of Uchkizil water reservoir, Surkhandarya water reservoir with a huge riverbed, Tuyabugiz water reservoir on the Ohangaran river was quickened [1].

According to it, the Ministry of production and preparation of agricultural products of Uzbekistan SSR, the Ministry of Irrigation of Uzbekistan SSR accepted the proposal of the executive committees of Samarkand, Bukhara and Kashkadarya provinces on the reclamation of 94 thousand hectares of virgin and new lands in 1965-1970, as well as, it was arranged to enlarge Kattakurgan water reservoir for 27 thousand hectares as the construction of the AmuKarakul canal in 15 thousand hectares and the AmuBukhara canal in 24 thousand hectares and the construction of the Chimkurgan, Pachkamar and Kalkamin water reservoir in 28 thousand hectares-in the suggested provinces[3].

Irrigation in Uzbekistan was developed in the period of 1950-1990. Because of the irrigation construction in the Republic in 1981-1990, the number of working water reservoirs reached 23 . The construction of 15 of them continued, and projecting 6 of them ran [2].

To solve ecological problems the "Complex Scientific-and-Technical Program for Environment Protection in the Republic of Uzbekistan" has been developed. In 1986-1990 a number of republican programs and laws on environment protection have been adopted and the Republican State Committee on environment protection has been set up; all sources of harmful effluents have been registered [5].

There are three main directions in ecological policy of the Republic of Uzbekistan.

The first is satisfaction of increasing demand in raw materials. The main approaches are: exploration of raw materials; reduction of land alienation to towns; efficient use of water resources [10].

The second - reduction of environment contamination, neutralization of harmful effect of waste products effluent on environment and human being. Here the following problem should be solved; purification of industrial-domestic waste and gas effluent, introduction of closed production cycles.

The third - preservation of nature dynamic balance, covering all its elements. This can be achieved by using the first two directions and special measures - protection of forests, creation of preserves, as well as carrying out erosion and mudflow prevention [5; p.66].

In 1990 water of Aral is abated to 39 meters (The height of Aral Sea reduced to 39 meters)[6]. The trouble of preservation of the Aral Sea became not only the internal Central Asian trouble but international as well. UNESCO and other international organizations and charitable societies got interested in this issue. For a long time the scientists from Uzbekistan, Kazakhstan, Turkmenistan carefully study the problem [9]. At present, a single conception is being developed. The idea is to preserve the Aral Sea or at least to decrease to the maximum the negative effects of drying out. The former fishing center of the sea was a town named Muynak. The town is now landlocked more than 30 kilometers from the water. Less than twentyfive years ago, Muynak was a seaport. In 1990, major of Muynak and its last harbormaster commented: "The water continued to go away while the salinity increased. The weather changed for the worse, with the summers getting hotter and the winters colder. The people feel salt on their lips and their eyes all the time. It's getting hard to open your eyes here"[4].

At present time some world countries are helping in these troubles. Today there is a committee called "Save Aral Sea". Unfortunately this global problem is not ending. What can we do to keep Aral Sea? Or how can we solve this problem so fast? Many scientists say that we must do following in order to save our poor Aral Sea. 1. Flowing rain and snow waters into Aral; 2. Turning of the mountain waters into Aral Sea.

\section{Conclusion.}

As a conclusion it is fair to emphasize that in $50-80$ of the XX century irrigation developed in Uzbekistan. The development of irrigation in the Republic caused to lots of critical aspects. As irrigation-land-reclamation developed highly at the result of cotton growing in the republic the land began to lose its fertility, deficiency of water resources increased year by year. As well as, at the result of reclaiming virgin lands, organization of many districts, state farms specialized to cotton growing, enlarging cotton fields and irrigating them improperly, not using water resources incorrectly there occurred serious problems like water deficiency. The irrigation structures built to develop cotton growing together with its positive sides caused 


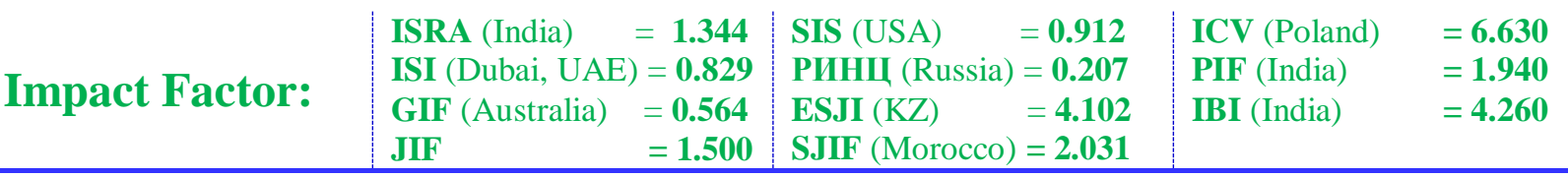

some critic aspects. Improper use of water resources, irrigating large sowing areas incorrectly, reclamation of virgin lands, organization of districts and state farms in those areas, at last, caused to water deficiency as well as to the Aral tragedy.

\section{References:}

1. Abdullayev, A. (2006) "Cotton monopoly: results and experiences (1917-1991)".Tashkent, Istiklal, -p.70.

2. Akramov, Z. (1989) "The Past, Present and Future of the Aral Sea".- Tashkent: Mekhnat, p.129.

3. (1993) Central State archive of the Republic of Uzbekistan, fund-R.2483, list 1, case 1993, p.141.

4. Enger, D. (1995) "Environmental Science. A study of interrelationships".Fifth edition. USA, McGraw-Hill, 1995. -p.301-302.

5. (1993) Independent Uzbekistan today.1993Tashkent: UZBEKISTON, -p.63-66.
6. (2018) Available: http://uz.wikipedia.org/wiki/ (Accessed: 10.01.2018).

7. (2000) Central State archive of the Republic of Uzbekistan, fund-R.2483, list 1, case 2000, p.43.

8. (1995) Central State archive of the Republic of Uzbekistan, fund-R.2483, list 1, case 1995, p.65.

9. (1999) Central State archive of the Republic of Uzbekistan, fund-R.2483, list 7, case 1999, p.55.

10. (1995) Central State archive of the Republic of Uzbekistan, fund-R.2483, list 1, case 1995, p.74. 